\title{
SVEIKATOS PRIEŽIŪROS KOKYBĖS LIGONINĖJE POKYČIAI VALSTYBĖS LYGIO EKSTREMALIOSIOS SITUACIJOS IR KARANTINO DÉL COVID-19 METU NEPAGEIDAUTINŲ IVYKIŲ ASPEKTU: ATVEJO ANALIZE்
}

\author{
Vinsas Janušonis ${ }^{1,2}$, Henrieta Janušonytė \\ ${ }^{1}$ Klaipedos universitetas, ${ }^{2}$ Klaipédos universitetiné ligonine
}

Raktažodžiai: nepageidautini ịvykiai, karantinas dèl Covid-19, sveikatos priežiūros kokybè.

\begin{abstract}
Santrauka
Sveikatos priežiūros kokybė ligoninèse ir vienas jos žymenu - nepageidautini įvykiai (kiekis, spektras, pasekmès) valstybès lygio ekstremaliosios situacijos ir karantino dèl Covid-19 metu gali skirtis nuo būklès ikiepideminiu laikotarpiu.

Tyrimo tikslas - ịvertinti nepageidautinų ịvykių ligoninejje pokyčius ir jų ịtaką sveikatos priežiūros kokybei valstybès lygio ekstremaliosios situacijos ir karantino dèl Covid-19 metu.

Atliekant tyrimą, analizuotos ịvairių šalių autorių mokslinės publikacijos, tirti nepageidautinų įvykių ekspertuoti pranešimai valstybès lygio ekstremaliosios situacijos ir karantino dèl Covid-19 metu 2020 m. ir tuo pačiu laikotarpiu 2019 metais. Atskleisti nepageidautinų ịvykių spektro, priežastinių veiksnių, rizikos laipsnių bei išvengiamumo pokyčiai ir jų priežastys. Duomenys palyginti su kitų šaliu patirtimi. Nustatyta, kad ịvairūs nepageidautinų ịvykių aspektai valstybės lygio ekstremaliosios situacijos ir karantino dèl Covid-19 metu ir tuo pačiu laikotarpiu iki Covid-19 epidemijos yra skirtingi.
\end{abstract}

\section{Ivadas}

Nepageidautini ịvykiai yra vienas svarbiausių sveikatos priežiūros kokybės ligoninėse žymenų. Jie pakankamai dažni - įvairių šalių autorių duomenimis, ligoninèse jų ịvyksta nuo 2,9 iki 16,6 proc. hospitalizuotuc pacientų [1-4]. JAV sveikatos priežiūroje nepageidautini ịvykiai, medicininès klaidos yra trečioji mirčių priežastis [5]. Dauguma nepageidautinų îvykių sveikatos priežiūroje, iš kurių daugiau nei pusę sudaro medicininès klaidos, dažnai turinčios rimtas pasekmes, ivvyksta ligoninèse [6]. Dažniausi nepageidautini ịvykiai sveikatos priežiūroje susiję su chirurgija, vaistais ir hospitalinemis infekcijomis [4].

Šalies ligoninèse, priklausomai nuo nepageidautinų ìvykių taksonomijos (šalies mastu jie pradèti registruoti tik nuo 2019 m.), jų spektras ir dažnis yra skirtingi. Klaipedos universitetinès ligoninès 15 metų nepageidautinų ịvykių tyrimo duomenimis, daugiau nei puse jų susiję su chirurgija (iskaitant kartotines operacijas), antroje vietoje - su akušerija ginekologija (didžioji dalis - tarpvietès plyšimas gimdymo metu), trečioje - su slauga (įskaitant griuvimus). Nepageidautinų îvykiu, susijusių su vaistais bei hospitaline infekcija - nedaug. Didelès rizikos nepageidautinų ịvykių - penktadalis, su pacientų mirtimi susijusių - 1,4 procento. Dviejų trečdalių nepageidautinų îvykių buvo galima visiškai ar iš dalies išvengti [7].

Nepageidautini ịvykiai yra neatsiejama sveikatos priežiūros sistemos ir jos organizacijų, sveikatos priežiūros proceso dalis. Nepageidautinų įvykių sveikatos priežiūroje priežastingumas siejamas su žmogiškuoju veiksniu - žmogus gali klysti, ribotai ar netinkamai naudoti žinias ir mokslinius ịrodymus, ar jų nežinoti $[8,9]$. Su nepageidautinais įvykiais ligoninèse susiję žmonès - medikai, pacientai, vadovai pasižymi labai skirtingomis individualiomis charakteristikomis, gebejjimais, kurie turi didelès reikšmès tiems ìvykiams atsirasti. Trečioji šalis (be pacientų ir medikų), turinti didelę įtaką nepageidautinu ịvykių atsiradimui, yra sveikatos priežiūros organizacija (ligoninè) ir pati sveikatos priežiūros sistema. Sisteminių organizacinių veiksnių svarba nepageidautinų ịvykių priežastinèje grandinèje yra labai didelė [10-12]. Vis délto nemaža dalis autorių mano, kad nepageidautinų ìvykių pagrindiné priežastis - sistemos ir medikų nesékmių, klaidų bei pacientų charakteristikų kombinacija [13-16]. Visas tris paminètas dedamąsias (pacientas, medikas, sveikatos priežiūros sistema), kurios turi įtakos nepageidautinų įvykių atsiradimui, veikia globalūs veiksniai - 
karai, epidemijos, gamtinès nelaimès, ekonominiai nuosmukiai, revoliucijos, techninès katastrofos ir kiti. Nors šie veiksniai antriniai, tačiau jų poveikis nepageidautinu ịvykiu sveikatos priežiūroje (ligoninèse) pokyčiams yra didžiulis $[3,17]$.

Nepageidautinų įvykių ligoninėse sumažinimas „iki nulio“ yra siekinys, tačiau labai sunkiai pasiekiamas, nes tai priklauso nuo aplinkos, kultūrinių, sisteminių ir instituciniu ypatumu $[18,19]$. Nepaisant didelių pastangų gerinti sveikatos priežiūros kokybę, mažinti nepageidautinų įvykių skaičių, jie kelia didelę grèsmę kokybei ir yra visuotine problema.

Nepageidautinus įvykius ligoninèse mažina infrastruktūros tobulinimas, medikų požiūrio ị darbą keitimas, institucijos politikos ir procedūrų laikymasis, didesnis dèmesingumas darbui ir pacientams, konkretus veiksmų planas ir kita [20-22].

Vienas iš antrinių veiksnių - Covid-19 pandemija, paveike nepageidautinų įvykių sveikatos priežiūroje spektrą, rizikos laipsni bei kiekị. Epidemija sukèlè daug nenuspejamų, nenumatytų chaotinių pokyčių pačioje sveikatos priežiūros sistemoje, neigiamai veikè veiklos procesus ir rezultatus. Paminètinas medikų trūkumas, Covid-19 liga sergančiųų antplūdis ligoninèse, patyrimo stoka, gydant Covid-19 sergančius pacientus, sumažėjęs paslaugų prieinamumas sergantiems kitomis ligomis, nuotolinių gydytojų konsultacijų trūkumai, psichoemocinis pacientu ir mediku stresas, sutrikusi komunikacija. Tai ne tik didino nepageidautinu ivykiu sveikatos priežiūroje, ypač ligoninèse, skaičių, bet ir keitè jų spektrą $[23,24]$. Reikejo atnaujinti ar kurti naujas nepageidautinu ivvykių pranešimų ir analizès sistemas, medikams prisitaikyti ir adaptuotis prie pokyčiu epidemijos sąlygomis $[25,26]$. Sutriko nepageidautinų îvykiu preven- cijos programų vykdymas. Gydytojams ir pacientams reikejjo ịprasti prie naujos aplinkos Covid-19 pandemijos sąlygomis - pakitusi aplinka tapo „normali“ [27].

Viena iš diskutuotinų temų yra Covid-19 ligos plitimas, jos igijimas ligoninėse - nepageidautinas įvykis, ar nauja realybè. Nurodoma, kad 12-15 proc. hospitalizuotų pacientų Covid-19 infekciją igijo ligoninėse, tačiau tokius nepageidautinus ìvykius, kaip užsikrètimą ligoninèje Covid-19 labai sunku įrodyti, nustatyti ir traktuoti kaip hospitalinę infekciją, todèl šiuo požiūriu ligoninių elgsena labai skirtinga [28-31]. Priskiriant Covid-19 infekuotus pacientus hospitalinèms infekcijoms, reikia įvertinti galimą hospitalizavimą paciento, jau sergančio Covid-19, tačiau dar inkubaciniame (2-14 dienų) periode, galimus sergančius lankytojus, paciento judejimą hospitalizacijos metu ir kitus aspektus [32-34].

1 lentelè. Nepageidautinų ịvykių pasiskirstymas pagal ligų gydymo profilius

\begin{tabular}{|l|c|c|c|c|c|c|}
\hline \multirow{2}{*}{ Metai } & \multicolumn{2}{|c|}{2019} & \multicolumn{2}{c|}{$\begin{array}{c}2020 \text { (VLES ir } \\
\text { karantinas) }\end{array}$} & \multicolumn{2}{c|}{ Pokytis 2020-2019 } \\
\cline { 2 - 7 } Gydymo profiliai & \multicolumn{2}{|c|}{$\mathrm{n}_{1}=94$} & \multicolumn{2}{c|}{$\mathrm{n}_{2}=98$} & \multicolumn{2}{c|}{$\mathrm{n}_{2}-\mathrm{n}_{1}=4$} \\
\cline { 2 - 8 } & $\mathrm{n}_{1}$ & proc. & $\mathrm{n}_{2}$ & proc. & $\mathrm{n}_{2}-\mathrm{n}_{1}$ & proc. \\
\hline Chirurgijos & 63 & 67,0 & 44 & 44,9 & -19 & $-22,1$ (SRS) \\
\hline Akušerijos ginekologijos & 26 & 27,7 & 15 & 15,3 & -11 & $-12,4$ (SRS) \\
\hline Palaikomojo gydymo ir slaugos & 0 & 0 & 24 & 24,5 & 24 & 24,5 (SRS) \\
\hline Vidaus ligų & 0 & 0 & -2 & 2,0 & 2 & 2,0 \\
\hline Anesteziologijos reanimacijos & 4 & 4,3 & 4 & 4,1 & 0 & $-0,2$ \\
\hline Kiti & 1 & 1,1 & 9 & 9,2 & 8 & 8,1 (SRS) \\
\hline
\end{tabular}

2 lentelė. Nepageidautinų įvykių pasiskirstymas pagal grupes

* Tie patys nepageidautini ịvykiai gali patekti i ịvairias grupes.

\begin{tabular}{|l|c|c|c|c|c|c|}
\hline \multirow{2}{*}{ Metai } & \multicolumn{2}{|c|}{2019} & \multicolumn{2}{c|}{$\begin{array}{c}\text { 2020 (VLES ir } \\
\text { karantinas) }\end{array}$} & \multicolumn{2}{c|}{ Pokytis 2020-2019 } \\
\cline { 2 - 7 } & \multicolumn{2}{|c|}{$\mathrm{n}_{1}=94$} & \multicolumn{2}{c|}{$\mathrm{n}_{2}=98$} & \multicolumn{2}{c|}{$\mathrm{n}_{2}-\mathrm{n}_{1}=4$} \\
\cline { 2 - 7 } & $\mathrm{n}_{1}$ & proc. & $\mathrm{n}_{2}$ & proc. & $\mathrm{n}_{2}-\mathrm{n}_{1}$ & proc. \\
\hline Pakartotinės operacijos & 50 & 53,2 & 44 & 44,9 & -6 & $-3,3$ \\
\hline NI susiję su gimdymu & 31 & 33,0 & 13 & 13,3 & -18 & 19,7 (SRS) \\
\hline NI susiję su infekcija & 8 & 8,5 & 4 & 4,1 & -4 & $-4,4$ \\
\hline NI susiję su operacija & 59 & 62,8 & 50 & 51,0 & -9 & $-11,8$ \\
\hline Griuvimai & 0 & 0 & 22 & 22,4 & 22 & 22,4 (SRS) \\
\hline NI susiję su diagnostika & 0 & 0 & 1 & 1,0 & 1 & 1,0 \\
\hline NI susiję su anestezija & 1 & 1,1 & 2 & 2,0 & 1 & 0,9 \\
\hline NI susiję su procedūra & 1 & 1,1 & 3 & 3,1 & 2 & 2,0 \\
\hline NI susiję su vaistais & 0 & 0 & 0 & 0 & 0 & 0 \\
\hline NI susiję su slauga & 0 & 0 & 2 & 2,0 & 2 & 2,0 \\
\hline Kiti NI & 0 & 0 & 7 & 7,1 & 7 & 7,1 (SRS) \\
\hline
\end{tabular}

3 lentelè. Nepageidautinų ịvykių pasiskirstymas pagal rizikos laipsnị

\begin{tabular}{|l|c|c|c|c|c|c|}
\hline \multirow{2}{*}{ Metai } & \multicolumn{2}{c|}{2019} & \multicolumn{2}{c|}{$\begin{array}{c}\text { 2020 (VLES ir } \\
\text { karantinas) }\end{array}$} & \multicolumn{2}{c|}{ Pokytis 2020-2019 } \\
\cline { 2 - 7 } $\begin{array}{l}\text { Rizikipsnis } \\
\text { laipsnis }\end{array}$ & \multicolumn{2}{|c|}{$\mathrm{n}_{1}=94$} & \multicolumn{2}{c|}{$\mathrm{n}_{2}=98$} & \multicolumn{2}{c|}{$\mathrm{n}_{2}-\mathrm{n}_{1}=4$} \\
\cline { 2 - 7 } & $\mathrm{n}_{1}$ & proc. & $\mathrm{n}_{2}$ & proc. & $\mathrm{n}_{2}-\mathrm{n}_{1}$ & proc. \\
\hline Minimali & 4 & 4,3 & 35 & 35,7 & 31 & 31,4 (SRS) \\
\hline Vidutine & 49 & 52,1 & 38 & 38,8 & -11 & $-13,3$ \\
\hline Didele & 36 & 38,3 & 34 & 34,7 & -2 & $-3,6$ \\
\hline Mirtis, susijusi su NI & 5 & 5,3 & 1 & 1,0 & -4 & $-4,3$ \\
\hline
\end{tabular}


Nepageidautinų ịvykių tikimybę didina pacientų izoliacija Covid-19 epidemijos metu, medikų darbas specifinèmis sąlygomis - ribotas kontaktas su pacientais, asmens apsaugos priemonès ir kita.

Izoliuotų dèl Covid-19 pacientų nepageidautini ịvykiai šiek tiek skiriasi nuo neizoliuotų pacientų ikiepideminiu laikotarpiu. Izoliuoti pacientai daugiau patyrè nepageidautinų ìvykių dẻl gydymo komplikacijų, hospitalinių infekcijų ir tokių, kurių buvo galima išvengti. Nepageidautinų ịvykių rizikos laipsnis tarp izoliuotų ir neizoliuotų pacientų iš esmès nesiskyrè $[35,36]$. Pažymima, kad nepageidautinų ivvykių išvengiamumo galimybès Covid-19 pacientams yra ribotos [37].

Nepageidautini ịvykiai Covid-19 pacientams dažnesni, jų daugiau ịvyksta prièmimo ir intensyviosios pagalbos (reanimacijos) skyriuose, dažnesni su chirurgija ir operacijomis susiję ịvykiai. Apie pusantro karto daugiau nepageidautinų ịvykių patiria vyresni kaip 60 metų Covid-19 pacientai. Daugumai Covid-19 pacientu nebuvo didelès nepageidautinų ìvykių rizikos $[18,38]$.

Covid-19 pandemijos metu medikų bei ligoninès vadovų sprendimus ir veiksmus varžo atsakomybės baimè, praẻjus epidemijai. Nepageidautinų įvykių Covid-19 pandemijos metu ligoninèse daugejja, tam yra daug priežasčių, kurios aptartos anksčiau. Vèliau, praejus epidemijai ar jos bangai, medikų ir ligoninių

4 lentelė. Nepageidautinų įvykių priežastiniai veiksniai (medikų vertinimas)

\begin{tabular}{|l|c|c|c|c|c|c|}
\hline \multirow{2}{*}{ Metai } & \multicolumn{2}{|c|}{2019} & \multicolumn{2}{c|}{$\begin{array}{c}2020 \text { (VLES ir } \\
\text { karantinas) }\end{array}$} & \multicolumn{2}{c|}{ Pokytis 2020-2019 } \\
\cline { 2 - 7 } $\begin{array}{l}\text { Priežastiniai } \\
\text { veiksniai }\end{array}$ & \multicolumn{2}{|c|}{$\mathrm{n}_{1}=94$} & \multicolumn{2}{c|}{$\mathrm{n}_{2}=98$} & \multicolumn{2}{c|}{$\mathrm{n}_{2}-\mathrm{n}_{1}=4$} \\
\cline { 2 - 7 } & $\mathrm{n}_{1}$ & proc. & $\mathrm{n}_{2}$ & proc. & $\mathrm{n}_{2}-\mathrm{n}_{1}$ & proc. \\
\hline $\begin{array}{l}\text { Individualios pacientų charak- } \\
\text { teristikos }\end{array}$ & 91 & 96,8 & 84 & 85,7 & -7 & 11,1 (SRS) \\
\hline $\begin{array}{l}\text { Individualios mediku charak- } \\
\text { teristikos }\end{array}$ & 0 & 0 & 3 & 3,1 & 3 & 3,1 \\
\hline Komandinio darbo veiksniai & 2 & 2,1 & 3 & 3,1 & 1 & 1,0 \\
\hline $\begin{array}{l}\text { Valdymo ir organizaciniai } \\
\text { veiksniai }\end{array}$ & 0 & 0 & 0 & 0 & 0 & 0 \\
\hline Darbo sąlygos & 0 & 0 & 1 & 1,0 & 1 & 1,0 \\
\hline Darbo įrankiai & 2 & 2,1 & 5 & 5,1 & 3 & 3,0 \\
\hline Kita & 4 & 4,3 & 7 & 7,1 & 3 & 2,8 \\
\hline
\end{tabular}

5 lentelè. Nepageidautinų įvykių priežastiniai veiksniai (ekspertų vertinimas)

\begin{tabular}{|l|c|c|c|c|c|c|}
\hline \multirow{2}{*}{ Metai } & \multicolumn{2}{|c|}{2019} & \multicolumn{2}{c|}{$\begin{array}{c}\text { 2020 (VLES ir } \\
\text { karantinas) }\end{array}$} & \multicolumn{2}{c|}{ Pokytis 2020-2019 } \\
\cline { 2 - 7 } $\begin{array}{l}\text { Priežastiniai } \\
\text { veiksniai }\end{array}$ & \multicolumn{2}{|c|}{$\mathrm{n}_{1}=94$} & \multicolumn{2}{|c|}{$\mathrm{n}_{2}=98$} & \multicolumn{2}{c|}{$\mathrm{n}_{2}-\mathrm{n}_{1}=4$} \\
\cline { 2 - 7 } & $\mathrm{n}_{1}$ & proc. & $\mathrm{n}_{2}$ & proc. & $\mathrm{n}_{2}-\mathrm{n}_{1}$ & proc. \\
\hline $\begin{array}{l}\text { Individualios pacientu charak- } \\
\text { teristikos }\end{array}$ & 94 & 100,0 & 85 & 86,7 & -9 & $\begin{array}{c}-13,3 \\
\text { (SRS) }\end{array}$ \\
\hline $\begin{array}{l}\text { Individualios medikų charak- } \\
\text { teristikos }\end{array}$ & 3 & 3,2 & 6 & 6,1 & 3 & 2,9 \\
\hline Komandinio darbo veiksniai & 2 & 2,1 & 7 & 7,1 & 5 & 5 \\
\hline $\begin{array}{l}\text { Valdymo ir organizaciniai } \\
\text { veiksniai }\end{array}$ & 0 & 0 & 0 & 0 & 0 & 0 \\
\hline Darbo sąlygos & 0 & 0 & 1 & 1,0 & 1 & 1,0 \\
\hline Darbo įrankiai & 1 & 1,1 & 3 & 3,1 & 2 & 2,0 \\
\hline Kita & 0 & 0 & 2 & 2,0 & 2 & 2,0 \\
\hline
\end{tabular}

vadovų sprendimai ir veiksmai, priimti krizès, didžiulių krūvių, personalo trūkumo, visuotinès baimès metu yra kriminalizuojami ir teisiškai persekiojami $[38,40]$.

Tyrimo tikslas - ịvertinti nepageidautinų îvykių ligoninejje pokyčius ir jų ịtaką sveikatos priežiūros kokybei valstybès lygio ekstremaliosios situacijos ir karantino dèl Covid-19 metu.

\section{Tyrimo objektas ir metodika}

Tyrimo objektas - nepageidautini ịvykiai Klaipèdos universitetinèje ligonineje (KUL).

Tyrimo metodai - literatūros analizè, nepageidautinų îvykių pranešimų formų analizè, statistinių duomenų grupavimas ir analizè, lyginamoji turinio analize, apibendrinimai ir išvados.

Tyrimui atlikti buvo naudojama KUL nepageidautinų ịvykių pranešimų formų analizè. Forma parengta autoriaus, vẻliau papildyta, atsižvelgiant i LR sveikatos apsaugos ministerijos reikalavimus.

Buvo tiriami nepageidautini ịvykiai $2020 \mathrm{~m}$. vasario 26 d.- gruodžio $31 \mathrm{~d}$. (valstybès lygio ekstremaliosios situacijos (VLES) ir karantino dèl Covid-19 metu) ir 2019 m. vasario 26 d. - gruodžio $31 \mathrm{~d}$.

Šių periodų tyrimo duomenys analizuoti ir lyginti pagal pacientų amžių, lytị, nepageidautinų ịvykių priežastis, vietą, spektrą, pasekmes, išvengiamumo galimybes.

Statistinè duomenų analizė atlikta naudojant statistinio duomenų analizès paketo IBM SPSS 23,0 versiją ir MS Excel 2016 programą.

Duomenų skirtumas laikytas statistiškai reikšmingu, kai $p<0,05$ (statistinio pasikliautinumo lygmuo 95 proc.).

\section{Rezultatai ir jų aptarimas}

Analizuojamu 2019 metu periodu ligoninejje gydèsi 34684 pacientai, buvo pranešti ir registruoti 94 nepageidautini įvykiai (toliau - NI $)-0,3$ proc. 
visų hospitalizuotų pacientų. Analizuojamu 2020 m. (valstybès lygio ekstremaliosios situacijos ir karantino) periodu ligoninèje gydèsi 19762 pacientai, buvo pranešti ir registruoti $98 \mathrm{NI}-0,5$ proc. visų hospitalizuotų pacientų.

NI patyrusių vyrų $2019 \mathrm{~m}$. buvo 30,9 proc., 2020 m. $-50,0$ proc., moteru 69,1 proc. 2019 m. ir 50,0 proc. -2020 $\mathrm{m}$. Vyresnių nei 50 metų pacientų, patyrusių NI, $2019 \mathrm{~m}$. buvo 61,7 proc., 2020 m. $-74,5$ procento.

Valstybès lygio ekstremaliosios situacijos ir karantino dèl Covid-19 metu pranešta ir registruota daugiau nepageidautinų ịvykių, juos patyre daugiau vyrų bei vyresnių nei 50 metų pacientų. Tai atitinka literatūros duomenis [35, 38].

Analizuojant NI pagal ligų gydymo profilius (1 lentelè), matome, kad dauguma jų susiję su chirurgija, tarp jų - su kartotinèmis operacijomis. Tai atitinka literatūros duomenis, kad su chirurgija susijusių NI yra 27-74,9 procentai [9,41]. 2020 m. sumažèjo chirurgijos profilio ir akušerijos ginekologijos profilio NI ir padaugèjo palaikomojo gydymo ir slaugos NI (statistiškai reikšmingas skirtumas - SRS).

Tikètina, kad šiam rezultatui turèjo itakos medicinos ir pagalbinio personalo perskirstymas, santykinis jo stygius, pacientų psichoemocinè būsena, Covid-19 ligos baimè.

NI grupių analizè (2 lentelè) parodè, $\operatorname{kad} 2020$ m. sumažèjo NĮ, susijusių su gimdymu ir su operacija, tačiau padidèjo griuvimų skaičius.

Pažymètina, kad 2020 m. chirurginių operacijų ligoninès stacionare atlikta 13670 - 28,1 proc. mažiau, nei $2019 \mathrm{~m}$. (19024).

Vertinant NI rizikos laipsni (3 lentelè), matoma, kad 2020 m. ženkliai padidejjo minimalios rizikos (nesant pasekmių) NI ir sumažejo vidutinès bei didelès rizikos NI, o taip pat mirčių, susijusių su NIt.

Mirčių, susijusių su NI 2019 m. dalis (5,3 proc.) ligoninejje buvo palyginti
6 lentelè. Nepageidautinų ịvykių išvengimo galimybės (medikų vertinimas)

\begin{tabular}{|l|c|c|c|c|c|c|}
\hline \multirow{2}{*}{ Metai } & \multicolumn{2}{|c|}{2019} & \multicolumn{2}{c|}{$\begin{array}{c}\text { 2020 (VLES ir } \\
\text { karantinas) }\end{array}$} & \multicolumn{2}{c|}{$\begin{array}{c}\text { Pokytis } \\
\mathbf{2 0 2 0} / \mathbf{2 0 1 9}\end{array}$} \\
\cline { 2 - 7 } Vertinimas & \multicolumn{2}{|c|}{$\mathrm{n}_{1}=94$} & \multicolumn{2}{c|}{$\mathrm{n}_{2}=98$} & \multicolumn{2}{c|}{$\mathrm{n}_{2}-\mathrm{n}_{1}=4$} \\
\cline { 2 - 7 } & $\mathrm{n}_{1}$ & proc. & $\mathrm{n}_{2}$ & proc. & $\mathrm{n}_{2}-\mathrm{n}_{1}$ & proc. \\
\hline Buvo galima išvengti & 3 & 3,2 & 7 & 7,1 & 4 & 3,9 \\
\hline Iš dalies buvo galima išvengti & 47 & 50,0 & 51 & 52,1 & 4 & 2,1 \\
\hline Nebuvo galima išvengti & 44 & 46,8 & 40 & 40,8 & 4 & $-6,0$ \\
\hline
\end{tabular}

7 lentelè. Nepageidautinų ịvykių išvengimo galimybès (ekspertų vertinimas)

\begin{tabular}{|l|c|c|c|c|c|c|}
\hline \multirow{2}{*}{ Metai } & \multicolumn{2}{c|}{$\mathbf{2 0 1 9}$} & \multicolumn{2}{c|}{$\begin{array}{c}\text { 2020 (VLES ir } \\
\text { karantinas) }\end{array}$} & \multicolumn{2}{c|}{ Pokytis 2020/2019 } \\
\cline { 2 - 7 } Vertinimas & \multicolumn{2}{|c|}{$\mathrm{n}_{1}=94$} & \multicolumn{2}{c|}{$\mathrm{n}_{2}=98$} & \multicolumn{2}{c|}{$\mathrm{n}_{2}-\mathrm{n}_{1}=4$} \\
\cline { 2 - 7 } & $\mathrm{n}_{1}$ & proc. & $\mathrm{n}_{2}$ & proc. & $\mathrm{n}_{2}-\mathrm{n}_{1}$ & proc. \\
\hline Buvo galima išvengti & 6 & 6,4 & 12 & 12,2 & 6 & 5,8 \\
\hline Iš dalies buvo galima išvengti & 26 & 27,7 & 52 & 53,1 & 26 & 25,4 (SRS) \\
\hline Nebuvo galima išvengti & 62 & 65,9 & 34 & 34,7 & -28 & $-31,2$ (SRS) \\
\hline
\end{tabular}

didelè - 2000-2014 m. ši dalis sudare tik 1,4 proc. [11]. Kiti autoriai, išanalizavę daugelị mokslinių publikacijų, nurodo, kad mirčių, susijusių su Nİ, ligoninėse būna 8 proc. nuo visų Nİ [4]. Tai, kad didelès rizikos Nİ ligoninèse Covid-19 karantino metu būna mažiau, atitinka literatūros duomenis [38], nors kai kurie autoriai pažymi, kad Nİ rizikos laipsnis (pasekmès) Covid-19 epidemijos laikotarpiu nesiskyrè [36].

Medikų vertinimu, pakito kai kurie Nİ priežastiniai veiksniai (4 lentelè): 2020 m. sumažejo NI dèl individualių paciento charakteristikų ir šiek tiek padidejjo dèl individualių medikų charakteristikų bei darbo įrankių trikdžių. Tai atitinka literatūros duomenis $[42,3]$.

Ekspertų vertinimas (5 lentelè) iš esmès panašus. Daugelis autorių pažymi, kad individualios paciento charakteristikos yra vienas pagrindinių NI priežastinių veiksnių $[1,10,43]$.

NIt išvengimo galimybių (medikų vertinimu) analizè (6 lentelè) parodè, kad 2020 m. sumažejo Nİ, kurių nebuvo galima išvengti ir šiek tiek padidejo NI, kuriu visiškai ar iš dalies buvo galima išvengti. Ekspertų vertinimas šiuo aspektu buvo daug griežtesnis $-2020 \mathrm{~m}$. Nİ buvo galima visiškai ar iš dalies išvengti beveik trečdaliu daugiau, nei 2019 metais (7 lentelè). Tai atitinka literatūros duomenis, kad Covid-19 epidemijos laikotarpiu NI galima išvengti daugiau [35, 36], tačiau kiti autoriai teigia, kad Covid-19 sergantiems pacientams NI išvengimo galimybès yra ribotos [37].

Palyginamoji NI analizè valstybès lygio ekstremaliosios situacijos ir karantino metu $2020 \mathrm{~m}$. ir tuo pačiu laikotarpiu 2019 m. parodè, kad įvairūs NI aspektai nèra tapatūs, tačiau sveikatos priežiūros kokybès pokyčiams jie įtakos neturèjo [44].

\section{Išvados}

1. Valstybès lygio ekstremaliosios situacijos ir karantino dèl Covid-19 metu Klaipèdos universitetinèje ligoninèje $2020 \mathrm{~m}$. nepageidautinų ìvykių buvo daugiau, nei tuo pačiu metu nesant epidemijos 2019 m., tačiau sveikatos priežiūros kokybės pokyčiams jie ịtakos neturèjo. 
2. Nepageidautinų įvykių struktūra ir spektras iš esmès nesikeitè, tačiau 2020 m., palyginus su tuo pačiu laikotarpiu 2019 m., sumažèjo chirurgijos profilio (mažejo operacinis aktyvumas) ir padidejo su slauga susijusių nepageidautinų ivykių, ypač griuvimų, skaičius.

3. Palyginus $2020 \mathrm{~m}$. ir $2019 \mathrm{~m}$. tuos pačius laikotarpius, sumažèjo vidutinès bei didelès rizikos nepageidautinų ịvykių ir su jais susijusių mirčių skaičius.

4. 2020 metais nepageidautini ịvykiai mažiau priklausė nuo individualių pacientų charakteristikų, nei tuo pačiu 2019 metų laikotarpiu.

5. Nepageidautinų i̇vykių išvengiamumo galimybės 2020 m. buvo didesnès, nei tuo pačiu laikotarpiu 2019 metais.

\section{Literatūra}

1. De Vries EN, Ramzattan MA, Smorenburg SM, et al. The incidence and nature of in -hospitals adverse events: a systematic review. BMJ Quality and Safety 2008;7:216-223.

https://doi.org/10.1136/qshc.2007.023622

2. Rafter N, Hickey A, Condell S, et al. Adverse events in health care: learning from mistakes. QJM: International Journal of Medicine 2015;108:273-277.

https://doi.org/10.1093/qjmed/hcu145

3. Janušonis V. Rizikos valdymas sveikatos priežiūros organizacijose: sisteminè teorinè-praktinė apžvalga. Klaipėda: S. Jokužio leidykla-spaustuvè, 2016.

4. Schwendimann R, Blatter C, Dhaini S, et al. The occurrence, types, consequences and preventability of in-hospital adverse events - a scoping review. BMC Health Services Research 2018; 18:521-531

https://doi.org/10.1186/s12913-018-3335-z

5. Makary MA, Daniel M. Medical error - the third leading cause of death in the US. BMJ 2016;353:i2139-i2149.

https://doi.org/10.1136/bmj.i2139

6. Lind DP, Andersen DR, Williams A. Medical errors in Iova: prevalence and patients' perspectives. Journal of Patients Safety 2020;16:e199:e204.

https://doi.org/10.1097/PTS.0000000000000523

7. Janušonis V. Adverse events - one of the most important health care quality indicators: a case study. European Scientific Journal 2017;13:288-300.

https://doi.org/10.19044/esj.2017.v13n12p288

8. Walshe K, Smith J. Healthcare management. Maidenhead: McGraw Hill Open University Press 2011.

9. Sousa P, Uva AS, Serranheira F, et al. Estimating the incidence of adverse events in Portuguese hospitals: a contribution to improving quality and patient safety. BMC Health Service Research 2014;14:311-321.

https://doi.org/10.1186/1472-6963-14-311

10. Thomas EJ, Studdent DM, Runciman WB, et al. A comparison of iatrogenic injury studies in Australia and the USA: content methods, casemix, population, patient and hospitals characteristics. International Journal of Quality in Health Care 2000;12:371-378.

https://doi.org/10.1093/intqhe/12.5.371

11. Janušonis V. Organizacinė elgsena ir kokybė sveikatos priežiūroje: integracinè sisteminė apžvalga. Klaipėda: S.Jokužio leidykla-spaustuvè, 2017.

12. Mira JJ, Lorenzo S, Carrillo I, et al. Lessons learned from reducing the negative impact of adverse events on patients health professionals and healthcare organizations. International Journal for Quality in Healthcare 2017;29:450-460.

https://doi.org/10.1093/intqhc/mzx056

13. Ramzattan M, Ziekenhuis $M$. The incidence and nature of in- hospital adverse events: a systematic review. Quality and Safety in Health Care 2008.

14. Anderson P, Davis R, Hanna GB, Vincent CA. Surgical adverse events: a systematic review. American Journal of Surgery 2013;206:253-262.

https://doi.org/10.1016/j.amjsurg.2012.11.009

15. Kennerly DA, Kudyakov R, da Graca B, et al. Characterization of adverse events detected in a large health care delivery system using an enhanced global trigger tool over a five year interval. Health Service Research 2014;49:1407-1425.

https://doi.org/10.1111/1475-6773.12163

16. Panagioti M, Khan K, Keers RN, et al. Prevalence, severity and nature of preventable patient harm across medical care settings: systematic review and meta-analysis. BMJ 2019; 366:14185. https://doi.org/10.1136/bmj.14185

17. Sunshine JE, Meo N, Kassebaum NJ, et al. Association of adverse events of medical treatment with mortality in the United States: a secondary analysis of the global burden of diseases, injuries, and risk factors study. JAMA Network Open 2019; 2: e18704.

https://doi.org/10.1001/jamanetworkopen.2018.7041

18. Clapper C, Merlino J, Stockmeier C. Zero harm: how to achieve patient and workforce safety in healthcare. New York: McGraw Hill Professional 2018.

19. Conolly W, Li B, Conroy R, et al. National and institutional trends in adverse events over time: a systematic review and meta-analysis of longitudinal retrospective patient record review studies. Journal of Patient Safety 2021;17:141-148. https://doi.org/10.1097/PTS.0000000000000804

20. Gandhi TK, Kaplan GS, Leape L, et al. Transforming concepts in patient safety: a progress report. BMJ Quality and Safety 2018; 27:1019-1026. https://doi.org/10.1136/bmjqs-2017-007756

21. Busch JM, Moretti F, Purgato M, et al. Dealing with adverse events: a meta-analysis on second victim coping strategies. Journal of Patient Safety 2020;16:e51-e60. https://doi.org/10.1097/PTS.0000000000000661

22. Padula WV, Nagarajan M, Davidson P, Pronovost P. Investing 
in skilled specialists to prow hospital infrastructure for quality improvement. Journal of Patient Safety 2021;17:51-55.

https://doi.org/10.1097/PTS.0000000000000623

23. Gandhi TK, Singh H. Reducing the risk of diagnostic error in the Covid-19 era. Journal of Hospital Medicine 2020;15:363-366. https://doi.org/10.12788/3461

24. Kansagra AP, Goyal MS, Hamilton S, et al. Collateral effect of Covid-19 on stroke evaluation in the United States. New England Journal of Medicine 2020;383:400-401. https://doi.org/10.1056/NEJMc2014816

25. Kasda E, Robson C, Saunders J, et al. Using event reports in real-time to identify and mitigate patient safety concerns during the covid-19 pandemic. Journal of Patent Safety and Risk Management 2020;25:142-243. https://doi.org/10.1177/2516043520953025

26. Le Craw F. Rapid adoption of resilience strategies during the Covid-19 pandemic. Journal of Patient Safety and Risk Management 2020;25:163-166. https://doi.org/10.1177/2516043520933718

27. Berwick DM. Covid-19: beyond tomorrow. Choices for the "new normal". JAMA 2020; 323:2125-2126.

https://doi.org/10.1001/jama.2020.6949

28. Rhee C, Baker M, Vaidya V. CDC prevention epicentres program. Incidence of nosocomial Covid-19 in patients hospitalized at a large US academic medical center. JAMA Network Open 2020;3:e2020498.

https://doi.org/10.1001/jamanetworkopen.2020.20498

29. Voidazan S, Albu S, Toth R, et al. Health care-associated infections- a new pathology in medical practice? International Journal of Environmental Research and Public Health 2020;17:760-760.

https://doi.org/10.3390/ijerph17030760

30. Kodadek L, Berger J, Hant E. Guidance vs. quidlines: the role of evidence-based medicine in the Covid-19 pandemic. Journal of Patient Safety and Risk Management 2020; 25:216-218. https://doi.org/10.1177/2516043520965844

31. Barranco R, Du Tremoul LVB, Ventura F. Hospital aquired SARS-Cov2 infections in patients: inevitable conditions or medical malpractice? International Journal of Environmental Research and Public Health 2021;18:489-498. https://doi.org/10.3390/ijerph18020489

32. Lauer SA, Grantz H, Bi Q, et al. The incubation period of coronavirus diseases 2019 (Covid-19) from publicly reported confirmed cases: estimation and application. Annals of Internal Medicine 2020;172:577-582. https://doi.org/10.7326/M20-0504

33. Zhou Q, Gao Y, Wang X, et al. Nosocomial infection among patients with Covid-19, SARS and MERS: a rapid review and meta-analysis. Annals of Translational Medicine 2020; 8:629-631.

https://doi.org/10.21037/atm-20-3324
34. Rickman HM, Rampling T, Shaw K, et al. Nosocomial transmission of Covid-19: a retrospective study of 66 hospital a quired cases in a London teaching hospital. Clinical Infectious Diseases 2020.

https://doi.org/10.1093/cid/ciaa816

35. Jimenez-Pericas F, DeCastro MT, Pastor-Valero M, et al. Higher incidence of adverse events in isolated patients compared with nonisolated patients: a cohort study. BMJ Open 2020;10: e035238.

https://doi.org/10.1136/bmjopen-2019-035238

36. Purssell E, Gould D, Chudleigh J, et al. Impact of isolation on hospitalized patients who are infections: systematic review with meta-analysis. BMJ Open 2020;10:e030371.

https://doi.org/10.1136/bmjopen-2019-030371

37. Astier A, Carlet J, Hoppe-Tichy T, et al. What is the role of technology in improving patient safety? A French, German and UK healthcare professional perspective. Journal of Patient Safety and Risk management 2020; 25:219-224.

https://doi.org/10.1177/2516043520975661

38. Taylor MA, Kepner S, Gardner LA, Jones R. Patient safety concerns in Covid-19 related events: a study of 343 event reports from 71 hospitals in Pennsylvania. Patient Safety Journal 2020; 2:18-27. https://doi.org/10.33940/data/2020.6.3

39. Oliva A, Caputo M, Grassi S, et al. Liability of health care professionals and instructions during Covid-19 pandemic in Italy: symposium proceeding and position statement. Journal of Patient Safety 2020;16:e299-e302. https://doi.org/10.1097/PTS.0000000000000793

40. di Luca A, Vetrugno G, Pascali VL, et al. Perspectives on patients safety and medical malpractice: a comparison of medical and legal systems in Italy and the United States. Journal of Patient Safety 2019;15:e78-e81.

https://doi.org/10.1097/PTS.0000000000000460

41. Kable AK, Gibberd RW, Spigelman AD. Adverse events in surgical patients in Australia. International Journal of Quality in Health Care 2002;14:269-76.

https://doi.org/10.1093/intqhe/14.4.269

42. Wu AW, Buckle P, Belland T, et al. Supporting the emotional well-being of health care workers during the Covid-19 pandemic. Journal of Patients Safety and Risk Management 2020; 25:93-96.

https://doi.org/10.1177/2516043520931971

43. Classen DC, Resar R, Griffin F, et al. Global trigger tool shows that adverse events in hospitals may be ten times greater than previously measured. Health Affairs 2011;30:581-589. https://doi.org/10.1377/hlthaff.2011.0190

44. Janušonis V. Sveikatos priežiūros ir tinkamumo pokyčiai karantino dèl Covid-19 epidemijos metu: pacientų nuomonè ir vertinimas (atvejo analizè). Sveikatos mokslai, 2020;30:72-79. https://doi.org/10.35988/sm-hs.2020.181 
CHANGES IN THE QUALITY OF HEALTH CARE IN THE HOSPITAL DURING THE STATE-LEVEL EMERGENCY AND COVID-19 QUARANTINE: ADVERSE EVENT ASPECT (CASE STUDY) V. Janušonis, H. Janušonytė

Keywords: adverse events, Covid-19 quarantine, health care quality.

Summary

Adverse events are one of the most important markers of quality in hospitals. Various global factors, including pandemics, influence changes in adverse events in hospitals.

The aim of the study - to evaluate the changes in adverse events in hospital and their impact on health care quality during state-level emergency and Covid-19 quarantine.

Material and methods. Research object - adverse events in Klaipeda University Hospital.

Research methods - analysis of scientific literature, data analysis of adverse events reporting forms, comparative content analysis and synthesis, summaries and conclusions.

Inpatients adverse events from February 26 to December 31, 2020 (during state-level emergency and Covid-19 quarantine) were studied and compared to the same period in 2019.

Analysis of statistical data was done using the software SPSS version 23.

Results. In 2020, 0,3\% of adverse events from all hospitalized patients were reported and registered at the hospital, compared to $0,5 \%$ in 2019. During state-level emergency and Covid-19 quarantine in 2020 more adverse events have been reported and recorded in more men and patients over 50 years of age. During this period there was a decrease in surgical and obstetrics - gynecology and an increase in nursing adverse events. There was a decrease in birth- related and related to operations adverse events, but an increase in the number of patients' falls.

Assessing the degree of risk of adverse events, it was found that in 2020 there was a significant increase in minimal risk and a decrease in medium-and high-risk adverse events, as well as related deaths.

Examining the causal factors of the adverse events we see, that according to doctors and experts, they decreased due to the individual characteristics of the patients in 2020.

Adverse events avoidance analysis showed reducing the number of unavoidable events and an increase in the number of events that could be completely or partially avoided by doctors assessment.

According to experts, in 2020 more adverse events could have been avoided.

Conclusions. There were more adverse events during the statelevel emergency and Covid-19 quarantine at the Klaipeda University hospital than at the same preepidemic time, but they did not effect the health care quality changes.

The structure, spectrum and causes of adverse events did not change significantly during state-level emergency and Covid-19 quarantine.

The degree of risk (consequences) of adverse events during state-emergency and Covid-19 quarantine was milder, less dangerous to the patients' health. The chances of adverse events avoidance during state-emergency and Covid-19 quarantine were higer than in 2019.

Correspondence to: janusonis@kul.lt

Gauta 2021-04-09 